Philip Zander

\title{
Council liability for leaky buildings in New Zealand: An analysis of McNamara $v$ Auckland City Council.
}

\author{
Submitted for the LLB (Honours) Degree
}

Faculty of Law

Victoria University of Wellington

2013 


\section{Contents (References - table of contents)}

I

INTRODUCTION.

A Facts 5

B Key Issues . 6

II INTRODUCTION TO NEGLIGENCE FOR DEFECTIVE BUILDINGS ........... 6

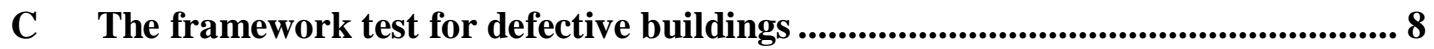

$1 \quad$ Anns Two stage approach in New Zealand.......................................... 8

III THE DIFFERENCE BETWEEN THE MAJORITY AND MINORITY ............10

2 Issue One - Duty of Care to check .......................................................10

3 Issue Two - Duty of Care in relation to accuracy of LIM reports .........14

$4 \quad$ Issue Three - s50(3) Good faith defence................................................15

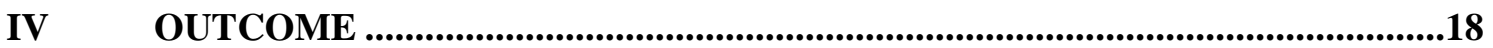

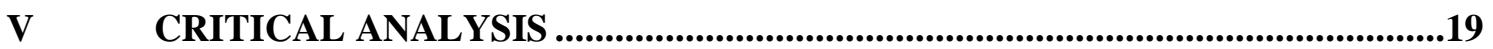

D Issue One: Duty of Care to inspect...............................................................................19

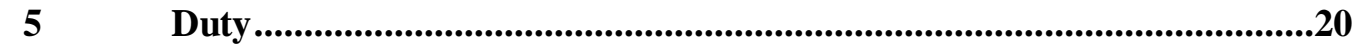

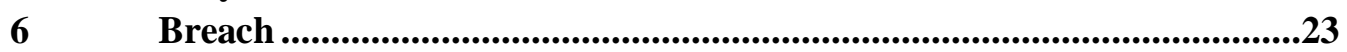

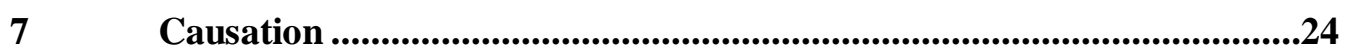

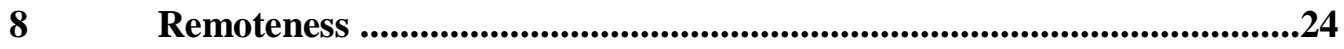

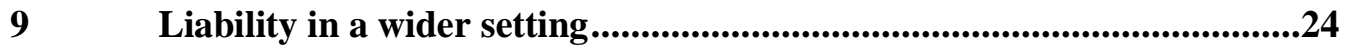

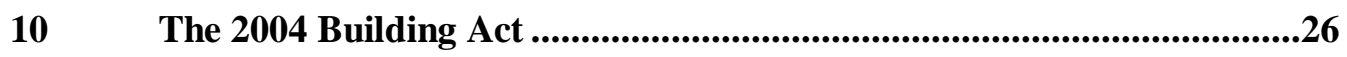

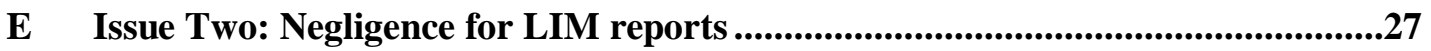

F Issue Three: The s50(3) good faith defence....................................................28

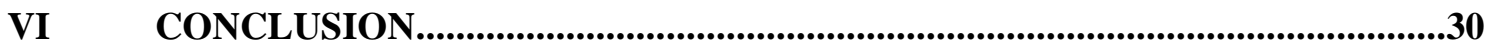

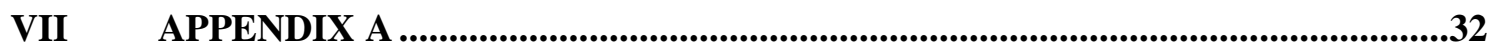

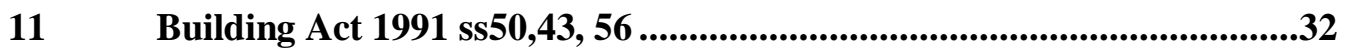

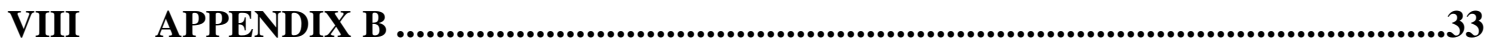

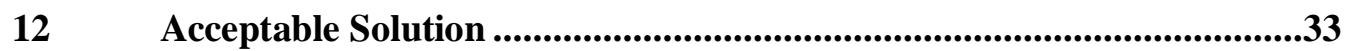

13 Clause E2-EXTERNAL MOISTURE.................................................33

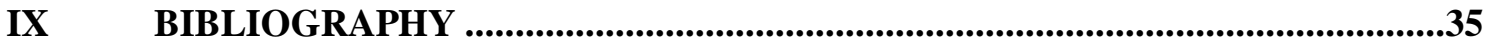

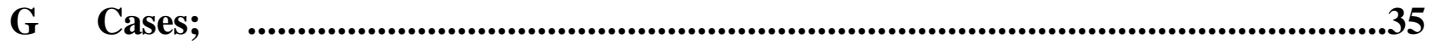

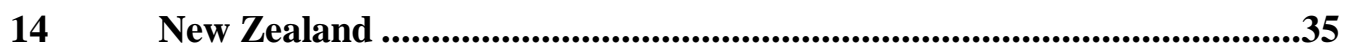

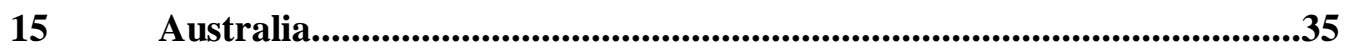

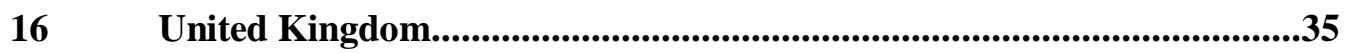

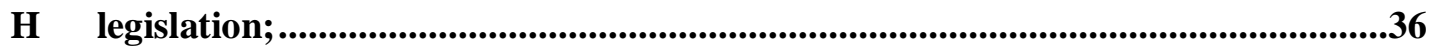

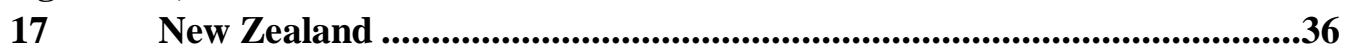

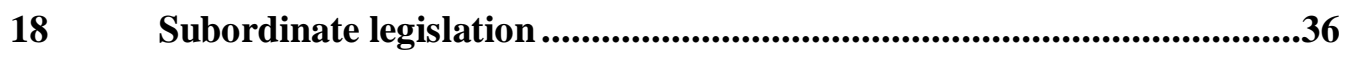

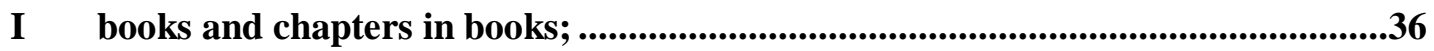

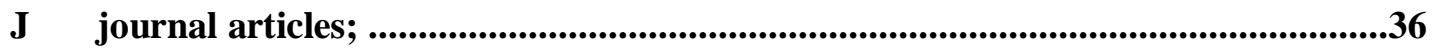

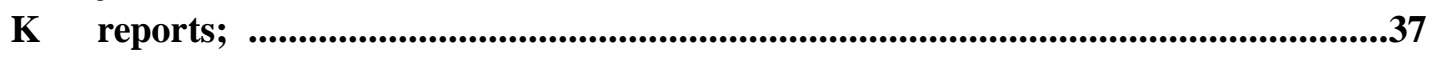

L Internet Resources .........................................................................................................37

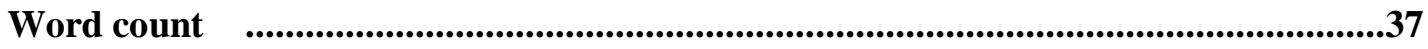




\begin{abstract}
This paper discusses the Supreme Court decision in McNamara v Auckland City Council. As McNamara is on the fringes of the existing body of law, the Supreme Court had a difficult decision on whether to extend liability, in line with the general development of this area of law or to restrict liability and reverse the earlier trends. William Young, McGrath and Blanchard JJ in the majority held that the Auckland City Council was not in a proximate relationship. The Council owed no duty of care to inspect the procedural validity of the building certificates or the validity of the code compliance certificate in the LIM report. Joined by Tipping J, the majority further concluded the s50(3) good faith defence would also prevail in both situations. Elias CJ dissented on all issues. This paper analyses the decisions and available facts against the accepted negligence framework and analyses policy issues concluding that the approach of Elias CJ is to be preferred to harmonise defective building law.
\end{abstract}

\title{
Key Words
}

Negligence;

Defective Buildings;

LIM reports;

Good Faith;

Building Act 1991. 


\section{Introduction}

Negligence for defective buildings rose to prominence due to the prevalence of leaky buildings in New Zealand. The cost of leaky buildings was initially estimated at \$11.6 billion, with 42,000 homes affected. ${ }^{1}$ This is likely to increase due to the decision in Spencer on Byron which settled the law on commercial buildings, enlarging the potential pool of claimants. ${ }^{2}$ McNamara $v$ Auckland City Council is a negligence case outside the established area of liability for territorial authorities in regard to defective buildings. ${ }^{3}$

The McNamara family purchased the property in question, Arney Crescent, from developers. After the purchase, Arney Crescent was found to be leaky and proceedings were initiated. Due to its particular facts, McNamara was not a simple matter of following clear and accepted precedents. McNamara cannot be characterised as a case where the territorial authority inspected the property and was negligent, or where a certified building inspector inspected the property negligently. As such, arguments of policy prevailed in all decisions and the interpretation of the facts as deemed due to the preliminary nature of the proceedings played a key role in the reasoning. McNamara, on appeal from an application for summary judgment went to the Supreme Court and the majority found the Auckland City Council not liable.

This paper analyses McNamara, highlighting the key issues facing the Supreme Court at Part I and introducing defective building negligence at Part II. The differing opinions of the Supreme Court are discussed in Part III, with the view of the majority summarised at part IV. Part V of the paper discusses the facts in relation to the principles that guide negligence. Specific focus is on the negligence framework and the statutory interventions in defective buildings. The author concludes at Part VI by disagreeing with the decision of the majority and preferring Elias CJ's approach. Appendix A and Appendix B contain relevant legislation and information about the applicable building standard that are essential to the paper.

\footnotetext{
${ }^{1}$ Pricewaterhouse Coopers Weathertightness: Estimating the Cost (Department of Building and Housing, July 2009).

2 Sophie East A New Class of Leaky Building Litigants? (Bell Gully, November 2012).

${ }^{3}$ McNamara v Auckland City Council [2012] NZSC 34.
} 


\section{A Facts}

The developer of Arney Crescent engaged Approved Building Certifiers Ltd (ABC) to inspect for code compliance under the 1991 Building Act (The Act). As a private certifier this relieved the territorial authority, Auckland City Council, from having to conduct inspections. From the time of appointment through until $4^{\text {th }}$ December 2002 ABC was approved to certify for the weather tightness standard E2. ${ }^{4}$ On the $4^{\text {th }}$ December, a limitation was placed on ABC's authority by the Building Industry Authority (BIA). ${ }^{5}$ This limited ABC to approving weather tightness for the prescribed solution E2/AS1. E2/AS1 was an acceptable solution designed by the BIA to combat the leaky home syndrome that had developed. ${ }^{6}$ It only allowed traditional building materials and shapes to ensure houses were weathertight. Many houses that leaked utilised construction methods that would not fit within E2/AS1. ${ }^{7}$ Inspections for weather tightness occurred after $4^{\text {th }}$ December 2002 and a code compliance certificate was issued by ABC in April 2004. The code compliance certificate included approving for weather tightness. To a reasonably informed person, such as an employee of the council working in the building consents department, these certificates would not comply with E2/AS1 ${ }^{8}$. The certificates were accepted by the Auckland City Council on face value as ABC was a registered building inspector. The Council did not check to see whether the issued certificates were within ABC's authority.

The McNamara family purchased the house after being advised by the council that a code compliance certificate had been issued. This statement was treated as part of the LIM (Land Information Memorandum) report even though the family were notified by a phone

\footnotetext{
${ }^{4}$ E2 is a performance based standard which prescribed the conditions required for a house in order to be classified as weather tight; See Appendix B for more information.

${ }^{5}$ The BIA was established to certify building inspectors and maintain the building code amongst other duties. Its primary purpose was to issue standards and assure that construction methods utilised would achieve the desired purposes of the Building Act 1991.

${ }^{6}$ See Appendix B.

${ }^{7}$ See Report of the Overview Group on the Weathertightness of Buildings to The Building Industry Authority (Department of Building and Housing, August 2002).

${ }^{8}$ McNamara v Auckland City Council, above n3, at [69], [102] per Elias CJ dissenting.
} 
call. ${ }^{9}$ A LIM report includes all information known to a council about a property at the time, including building certificates, water rights and past issues affecting the property. ${ }^{10}$ The house was a leaky building and substantively failed to meet the weather tightness standards. The McNamara family spent $\$ 1,056,594.08$ to rectify the issues with Arney Crescent. ${ }^{11}$ While proceedings were issued against a wide array of parties, this case focussed on the liability of the territorial authority when a private certifier has been engaged.

\section{B Key Issues}

1. Did the Auckland City Council owe a duty of care to subsequent purchasers, here the McNamaras, to check building certificates against the register to see if they were within the authority of the building inspector?

a. If there is a duty of care owed, what standard of care was the council bound to meet?

2. Did the Auckland City Council owe a duty of care, under Hedley Byrne, in relation to the accuracy of information contained in the LIM report?

3. If it did owe a duty of care, does the good faith defence in s 50(3) of the Building Act 1991 apply?

4. Does the 2004 Building Act alter liability?

\section{Introduction to negligence for defective buildings}

Negligence in respect of defective buildings is one area of the tort where the duty element requires a close analysis. Because of the complexity of the situation, it is not categorised as a simple duty of care. It is a duty behind contractual obligations with other parties, with multiple other experts involved in the process. This makes it a difficult and potentially controversial area of law.

\footnotetext{
${ }^{9}$ At [169] per Blanchard, McGrath and William Young JJ.

10 Bannister and von Dadelszon LIM (Land Information Memorandum) Reports (Bannister and von Dadelszon, 2013).

${ }^{11}$ McNamara \& Anor as trustees of the PH McNamara Family Trust v Malcolm J Lusby Ltd \& Ors HC Auckland CIV 2006-404-002967, 10 September 2009 at [2].
} 
Negligence for defective buildings has been part of tort law in New Zealand since Bowen in the 1970's. ${ }^{12}$ The most significant challenge occurred in Hamlin. ${ }^{13}$ The Court of Appeal in Hamlin reviewed authority and declined to alter the existing law based on the unique circumstances of New Zealand. ${ }^{14}$ Richardson J provided six reasons which enabled New Zealand to follow a different path to the United Kingdom. ${ }^{15}$ On appeal, the Privy Council reviewed the case and declined to reverse the Court of Appeal's deliberate choice to follow its own path in this complex area of the law. ${ }^{16}$

Over the course of the development of negligence for defective buildings, Parliament had multiple opportunities to change the liability of territorial authorities through legislation. Despite the passage of new legislation, in particular the 1991 Building Act, Parliament has not altered the liability of territorial authorities in negligence, apart from the addition of limitation periods. ${ }^{17}$ This continued with the passage of the 2004 Building Act, although new warranties may affect who ultimately carries the financial burden. ${ }^{18}$

Most of the Supreme Court decisions focus on the 1991 Building Act and territorial authorities who inspect and certify for code compliance. Sunset Terraces ${ }^{19}$ and Spencer on Byron ${ }^{20}$ both refined prior analysis and created a framework for use in this special subset of negligence. Both cases impose wide ranging liability on territorial authorities despite the hurdles that other jurisdictions have faced, such as the ability to claim for economic loss and issues of proximity. ${ }^{21}$

\footnotetext{
${ }^{12}$ Stephen Todd (ed) The Law of Torts in New Zealand (6 ${ }^{\text {th }}$ ed, Brookers, Wellington, 2013) at 292; Bowen $v$ Paramount Builders (Hamilton) Ltd [1977] 1 NZLR 394 (CA).

${ }^{13}$ See Invercargill City Council v Hamlin [1996] 1 NZLR 513 (PC); Invercargill City Council v Hamlin [1994] 3 NZLR 513 (CA).

${ }^{14}$ Above, n13.

${ }^{15}$ See Invercargill City Council v Hamlin [1994] 3 NZLR 513 (CA) at 524/525; Murphy v Brentwood District Council [1990] 2 All ER (HL).

${ }^{16}$ See Invercargill City Council v Hamlin [1996] 1 NZLR 513 (PC).

${ }^{17}$ See Invercargill City Council v Hamlin [1994] 3 NZLR 513 (CA) at 518.

${ }^{18}$ Building Act 2004, ss396-399.

${ }^{19}$ North Shore City Council v Body Corporate 188529 [2010] NZSC 158 [Sunset Terraces].

${ }^{20}$ Body Corporate No. 207624 v North Shore City Council [2012] NZSC 83 [Spencer on Byron].

${ }^{21}$ Murphy v Brentwood District Council [1990] 2 All ER (HL) at 919-921 per Lord Keith, at 928-931 per Lord Bridge.
} 
Despite the wide ranging liability of territorial authorities, the standard setter, BIA is not liable for two reasons. Firstly, the BIA is not proximate enough to owners or subsequent purchasers. Secondly the alleged duty covers actions of a quasi-legislative or quasijudicial role over which no duty should exist. ${ }^{22}$ This may seem odd as the entity responsible for creating, writing and developing the building code as well as arbitrating disputes is not responsible for the effects of its code. The Grange was one of the first steps from the Supreme Court to limit liability in negligence for leaky buildings. ${ }^{23}$

As McNamara is on the fringes of the existing body of law, the Supreme Court had a difficult decision on whether to extend liability, in line with the general development of this area of law or to restrict liability and reverse the earlier trends.

\section{The framework test for defective buildings}

Hamlin deliberately departed from the House of Lords in Murphy by distinguishing the circumstances in New Zealand. Over time these ideas have evolved and become conceptually blurred in light of recent developments. ${ }^{24}$ The Anns two stage test is held to be the proper authority underlying the main question, in negligence, of whether it is "fair, just and reasonable to impose a duty of care”. ${ }^{25}$

\section{Anns Two stage approach in New Zealand}

The two stage Anns approach is split into two categories of proximity and policy. Despite the nature and contents of these categories not being discrete they continue to be used. ${ }^{26}$ Proximity deals with the relationship between the parties. ${ }^{27}$ The first stage is whether it is

\footnotetext{
22 Todd Torts in New Zealand, above n12 at 343-344.

${ }^{23}$ North Shore City Council v Attorney-General as Successor to the Assets and Liabilities of the Building Industry Authority [2012] NZSC 49 [The Grange].

${ }^{24}$ Michael Sharp “Spencer on Byron” (2013) 5 NZLJ 195.

${ }^{25}$ Couch v Attorney General [2008] NZSC 45 at [52] per Elias CJ, at [78] per Tipping J.

26 Todd Torts in New Zealand, above n12, at 147-156.

27 Todd Torts in New Zealand, above n12, at 147-156.
} 
reasonably foreseeable that damage may occur to the plaintiff by careless actions of the defendant. ${ }^{28}$ The Court then adds any extra elements that may arise on the specific facts of the case or area of the special duty. ${ }^{29}$ Policy deals with the public policy issues, usually looking at externalities, which may limit the scope of the duty owed or any class of potential claimants that duty could be owed to. ${ }^{30}$

The questions asked in McNamara are questions of whether the proximity and policy arguments that enabled a duty of care to exist in Hamlin can continue in a situation where a private certifier has been engaged.

\section{Proximity}

Proximity is established through the control that territorial authorities have over the building process. ${ }^{31}$ When a territorial authority inspects buildings, there is general reliance, by the purchasing public, on the inspection that enhances that proximity. ${ }^{32}$ This reliance cannot be diminished by the involvement of other professionals such as architects or engineers in the construction process. ${ }^{33}$

\section{Policy}

Policy and conceptual arguments in other jurisdictions favour negating a duty. ${ }^{34}$ These policy arguments, such as economic loss, are not as persuasive in New Zealand due to the long time period during which the decisions have stood and the lack of government action to intervene. ${ }^{35}$ Richardson $\mathrm{J}$ in Hamlin presented six policy reasons which justified a different approach to the United Kingdom. ${ }^{36}$ These reasons have been altered over

\footnotetext{
${ }^{28}$ Todd Torts in New Zealand, above n12, at 154-156.

${ }^{29}$ See Todd Torts in New Zealand, above n12, at 154-156.

${ }^{30}$ Todd Torts in New Zealand, above n12, at 154-156.

${ }^{31}$ Sharp "Spencer on Byron", above n25.

${ }^{32}$ Sharp "Spencer on Byron", above n25.

${ }^{33}$ Spencer on Byron, above n20, per McGrath and Chambers JJ at 67. Sunset Terraces, above n19, at [50] per Tipping J; [8] per Elias CJ.

${ }^{34}$ See Caparo Industries plc v Dickman [1990] 2 AC 605 (HL); Murphy v Brentwood District Council [1990] 2 All ER (HL).

${ }^{35}$ Spencer on Byron, above n20, at [284]-[285] per William Young dissenting.

${ }^{36}$ Invercargill City Council v Hamlin, above n17, at 524-525 per Richardson J.
} 
time. Sunset Terraces expanded liability from single stand-alone dwellings to residential buildings. ${ }^{37}$ Spencer on Byron expanded liability from residential buildings to any buildings, the majority concluding, there was no difference in principle or policy between building types. ${ }^{38}$

\section{The difference between the Majority and Minority}

The majority judgment by William Young $J$ was on behalf of himself, McGrath and Blanchard JJ. Tipping J concurred with the majority's conclusion on the s50(3) good faith defence but reserved his opinion on the other issues. Elias CJ, in the minority, dissented on all issues.

\section{Issue One - Duty of Care to check}

The majority focussed on the responsibilities of a territorial authority once a private building inspector has been engaged. ${ }^{39}$ In their view, the territorial authority was relegated to an administrative role once this occurred. ${ }^{40}$ The general reliance and control the territorial authority had over the building process was negated. Hence there was no proximate relationship. ${ }^{41}$ To fulfil its duty of care all the territorial authority had to do was ensure that the certificate was made by a registered building certifier. ${ }^{42}$ The majority's rationale was that $s(57)(3)(b)^{43}$ meant that territorial authorities were to be notified by the certifier or building owner if a limitation was placed on a building certifier's authority. ${ }^{44}$ If the council was notified in this manner its responsibilities are 'enlivened' and it was under a duty to inspect. ${ }^{45}$ If the territorial authority was notified, the proximate relationship was re-established. It was conceded by the Court of Appeal,

\footnotetext{
${ }^{37}$ Sunset Terraces, above n19, at [48]-[49] per Tipping J; at [7] per Elias CJ.

${ }^{38}$ Spencer on Byron, above n20, at [9]-[10] per Elias CJ; [26] per Tipping J; [215]-[218] per Chambers and McGrath JJ.

${ }^{39}$ McNamara v Auckland City Council, above n3, at [111],[123-129] per William Young J.

${ }^{40}$ At [136]-[141], [132] [168] per William Young J.

${ }^{41}$ At [168] per William Young J.

${ }^{42}$ At [121] per William Young J.

${ }^{43}$ Building Act 1991.

${ }^{44}$ McNamara v Auckland City Council, above n3, at [139], [166] per William Young J.

${ }^{45}$ At [9] per Elias CJ dissenting; see [132] assented to at [168] per William Young J.
} 
but not elaborated upon in the Supreme Court, that this duty was also enlivened if the territorial authority "well knew" that a certifier was acting outside its authority. ${ }^{46}$ To "well know" requires more knowledge than being notified by changes to the register. ${ }^{47}$ It appears that the Court of Appeal was intending that constructive knowledge cannot be imputed upon an employee to defeat good faith. ${ }^{48}$

Furthermore the costs associated with checking the compliance of every certificate would be detrimental to the marketplace competition envisaged by the 1991 Building Act, as it would be prohibitive on private inspectors. ${ }^{49}$ This occurs as the private inspectors are subject to a cost that their public counterparts are not.

A process to review ABC's existing contracts had already been undertaken by the BIA and $\mathrm{ABC}$ at the time of their limitation. ${ }^{50}$ For Auckland City Council to replicate this process would waste resources, time and effort on a process that had already been completed and achieve nothing. ${ }^{51}$

A territorial authority is also not bound to investigate the substantive components of a certificate. Requiring a process which checks the face value is equivalent to this. ${ }^{52}$ Even if it had checked the certificate, Auckland City Council should not have rejected the certificate as it was implicit in the findings of the BIA review of ABC's engagements that $\mathrm{ABC}$ was authorised to certify for the Arney Crescent property. ${ }^{53}$

\footnotetext{
${ }^{46}$ At [132], [168] per William Young J.

${ }^{47}$ At [118] per William Young J.

${ }^{48}$ See [132] per William Young J.

${ }^{49}$ At [133] per William Young J.

${ }^{50}$ At [118] per William Young J.

${ }^{51}$ At [164] per William Young J.

${ }^{52}$ At [165] per William Young J.

${ }^{53}$ See [118] per William Young J.
} 
Inspections of certificates to see whether they are within a certifier's authority is a form of "backstop" liability. ${ }^{54}$ It is a way of requiring territorial authorities to substantively check the content of the certificates which was barred under s50. ${ }^{55}$

The Building Act envisaged public and private competition. ${ }^{56}$ In order to fulfil this purpose, policy dictates that extra costs must not be involved when a private certifier is engaged. Utilising the modified Anns framework, there was no proximate relationship as the council was acting in an administrative role. ${ }^{57}$ Policy reasons also inhibit the finding of a duty of care as it is against the purpose of the Act, by discouraging competition and enabling backstop liability, akin to damages in public law. ${ }^{58}$ A territorial authority, under s24, had not assumed responsibility and to find otherwise would impose liability on the territorial authority when they are in a supervisory role, and should not be liable when acting merely in a supervisory role. To impose liability is not utilising the torts framework but making damages available in a public law sense against a territorial authority. ${ }^{59}$

The majority found that no duty of care could arise when a private certifier had been engaged unless the council had been notified in the correct manner ${ }^{60}$ or "well knew". ${ }^{61}$ It was not efficient to constantly check that certificates were within the authority of private inspectors. ${ }^{62}$ This had been checked at the beginning of the process, the building consent stage. The time, costs and effort involved were too high and would be detrimental to the purpose of the Act. ${ }^{63}$

\footnotetext{
${ }^{54}$ See [132] as assented to at [168] per William Young J.

${ }^{55}$ At [12] per Elias CJ dissenting.

${ }^{56}$ See William Young J.

${ }^{57}$ At [168] assenting to [132] per William Young J.

${ }^{58}$ At [132] assented to in [168] per William Young J.

${ }^{59}$ See [132] as assented to in [168] per William Young J.

${ }^{60}$ Building Act 1991, s57.

${ }^{61}$ McNamara v Auckland City Council, above n3, at [132] assented to in [168] per William Young J.

${ }^{62}$ At [121], [164],[165] per William Young J.

${ }^{63}$ At [121] per William Young J.
} 
Elias CJ dissented on all issues and implicitly the wisdom of the majority making assumptions before full facts had emerged. ${ }^{64}$ The Chief Justice examined the Building Act in detail and concluded that territorial authorities maintain a residual authority in certain situations. ${ }^{65}$ This authority enables them to take over the inspection of buildings when private certifiers have been engaged, even if they have not been notified of any limitations on the building inspector. ${ }^{66}$ Given the residual responsibility, it can be argued the council owed a duty of care to fulfil its responsibilities under the Act. ${ }^{67}$ As such the council needed to ensure that only certified building inspectors, with the authority to inspect for those elements, are inspecting for those elements. ${ }^{68}$ Elias CJ phrased this as requiring the council to at least ensure certificates met the s56 requirements. ${ }^{69}$ She noted that the scope of that duty may change depending on the facts through other areas such as breach and causation. ${ }^{70}$

The Chief Justice had particular focus on $\mathrm{s} 17,{ }^{71}$ which allowed a territorial authority to utilise the expertise of the BIA, through adjudication, when there are questions over whether a certificate is within the authority of a private certifier. This would reduce the potential financial or administrative burdens on the council raised by the majority. ${ }^{72}$ It also offered a way of preventing a council from checking the substantive content of a certificate, as against checking the prima facie content against the inspector's authority.

Elias CJ also questioned the accuracy in estimating costs of checking certificates in order to negate a duty. ${ }^{73}$ Whilst stressing the importance of private and public competition she held that without full facts it was inappropriate to allow this to influence the potential existence of a duty. ${ }^{74}$

\footnotetext{
${ }^{64}$ At [14] per Elias CJ dissenting.

${ }^{65}$ At [33]-[39], [91]-[94] per Elias CJ dissenting.

${ }^{66}$ At [91] per Elias CJ dissenting.

${ }^{67}$ At [91] per Elias CJ dissenting.

${ }^{68}$ At [94], [103] per Elias CJ dissenting.

${ }^{69}$ At [103] per Elias CJ dissenting.

${ }^{70}$ At [108] per Elias CJ dissenting.

${ }^{71}$ Building Act 1991.

${ }^{72}$ McNamara v Auckland City Council, above n3, at [102] per Elias CJ dissenting.

${ }^{73}$ At [97]-[99] per Elias CJ dissenting.

${ }^{74}$ At [99] per Elias CJ dissenting.
} 
The Chief Justice also distinguished between substantive checking of building certificates and the procedural checks that were envisaged by the McNamara family. ${ }^{75}$ The difference is between, checking what the certificate prima facie is certifying for against the authority of the inspector and checking the substantive content of that certificate against the applicable building standard. ${ }^{76}$ In this case, the difference was between asking whether ABC Ltd could issue general E2 certificates and checking that the building actually met the standards of E2.

As changes to the register happened regularly, especially in relation to weather tightness in 2002, territorial authorities were "on alert". 77 This heightened awareness required more rigorous checks for compliance. ${ }^{78}$ Territorial authorities are not able to ignore their responsibilities under the Act as espoused by the majority. ${ }^{79}$ As the Auckland City Council had these responsibilities, subsequent purchasers are able to rely on the acceptance of the certificates as providing for building code compliance and that the correct procedures have been carried out by the council. The operation of the good faith defence, explained below at issue three, would prevent this duty from stretching into the substantive nature of the certificates. ${ }^{80}$

\section{Issue Two - Duty of Care in relation to accuracy of LIM reports}

The majority accepted that a territorial authority issuing a LIM report owes a duty of care in relation to its accuracy. ${ }^{81}$ This also extends to any responses to information requests associated with the LIM process. ${ }^{82}$ They also professed doubts as to whether the

\footnotetext{
${ }_{75}$ At [11],[12],[26], [32]-[32] [87]-[90] per Elias CJ dissenting.

${ }^{76}$ At [87]-[88] per Elias CJ dissenting.

${ }^{77}$ At [74-76] per Elias CJ dissenting.

${ }^{78}$ At [76] per Elias CJ dissenting.

${ }^{79}$ At [11]-[14]. [94] per Elias CJ dissenting.

${ }^{80}$ At [87] per Elias CJ dissenting.

${ }^{81}$ At [92]-[98] per Elias CJ dissenting; At [169] per William Young J.

${ }^{82}$ At [169] per William Young J.
} 
McNamara family, in fact, relied on the information but accepted that they did for the purposes of the decision. ${ }^{83}$

This claim failed because of the factual matrix. ${ }^{84}$ The code compliance certificate was regular on its face and as such, the territorial authority was bound to accept it. They are not entitled to investigate the certificate and it cannot be held that they were negligent. ${ }^{85}$ The representation was literally true in a factual sense and "could not be construed as implying the certificate had been issued in conformity with limitations placed on ABC's certifying competency". ${ }^{86}$

The Chief Justice stated that the points discussed by the majority were contradictory to the decision in Altimarloch the majority cited. ${ }^{87}$ Rather than answer this issue, she left this question open to be decided in a later case. The decision in Altimarloch is briefly discussed later in this paper.

\section{Issue Three - s50(3) Good faith defence}

Tipping J agreed with the conclusion of the majority on this issue. The good faith defence provides immunity to territorial authorities in situations where private certifiers have been engaged ${ }^{88}$ The construction of s50 makes more sense if references to s56 and s43 are not read literally. ${ }^{89}$ The inclusion of these sections was intended to provide a guide as to what type of certificates the defence applies to. ${ }^{90}$ As the certificate was valid on the surface and there was no indication it was outside the inspector's authority, a territorial authority

\footnotetext{
${ }^{83}$ At [169]-[170] per William Young J.

${ }^{84}$ At [169]-[170] per William Young J.

${ }^{85}$ At [169]-[170] per William Young J.

${ }^{86}$ At [170] per William Young J.

${ }^{87}$ At [10] per Elias CJ.

${ }^{88}$ See [156] per William Young J; [178] per Tipping J.

${ }^{89}$ At [179] per Tipping J.

${ }^{90}$ At [179] per Tipping J.
} 
is acting in good faith when relying on that certificate. ${ }^{91}$ Good faith, for the purposes of s50(3), means an absence of bad faith. ${ }^{92}$

The majority perceived that it would be difficult to admit an "aggregation of information" argument within the standard. "A3 "Aggregation of information", is similar to corporate liability. ${ }^{94}$ Information of individual officers is treated as information known to the entity, having been aggregated from those officers. An aggregation of information would allow lesser wrongs (negligent wrongs) to amount to a breach of the good faith standard. ${ }^{95}$ Allowing an aggregation approach would equate the negligence standard with good faith standard. ${ }^{96}$ This cannot be what was intended by Parliament and the narrower meaning is to be preferred. ${ }^{97}$

It was noted that, even if the majority were wrong on issue 2, in relation to Hedley Byrne liability, the s50(3) good faith defence prevailed. ${ }^{98}$ This is because the council officer issuing the LIM report was relying on a code compliance certificate, which is an included document for the purposes of $\mathrm{s} 50 .{ }^{99}$ There was no evidence to suggest the council office was acting in any manner other than with good faith. ${ }^{100}$

William Young J was critical of the approach of Elias CJ. The purpose of s50(3) was to protect the council when it relied on documents in good faith and those documents were, on the surface, valid. ${ }^{101}$ If investigation was required, this would reduce the impact of this section to instances where a territorial authority investigated the substantive contents of

\footnotetext{
${ }^{91}$ At [156] per William Young J; [178]-[179] per Tipping J.

${ }^{92}$ At [173]; per Tipping J.

${ }^{93}$ At [163] per William Young J;[176] per Tipping J.

${ }^{94}$ See [32] per Elias CJ dissenting.

${ }^{95}$ At [160]-[163] per William Young J; [176] Per Tipping J.

${ }^{96}$ At [176] per Tipping J; [160] per William Young J.

${ }^{97}$ At [160] per William Young J; [173]-[174] per Tipping J.

${ }^{98}$ At [170] per William Young J.

${ }^{99}$ At [170] per William Young J.

${ }^{100}$ At [170] per William Young J.

${ }^{101}$ At [156]-[157] per William Young J.
} 
the certificate. ${ }^{102}$ To do so would create other problems and reduce the meaningfulness of this protection. ${ }^{103}$ The protection is essential for the purpose of the Act, public and private competition. ${ }^{104}$

Elias CJ viewed both the standard required and the proper construction of the Act differently. The standard of good faith can differ depending on the statutory regime. ${ }^{105} \mathrm{In}$ Mid Density a lesser standard was accepted for the purposes of the Environmental Planning and Assessment Act 1979 (NSW), which is analogous to this situation. ${ }^{106}$ As it is arguable a lesser standard may apply, it should be fully argued before any conclusion is reached. ${ }^{107}$

Section 50 is also framed in a manner which explicitly links to $s 56$ and s43. ${ }^{108}$ Sections 56 and 43 define which certificates a council is bound to rely on from private certifiers. ${ }^{109}$ In particular a territorial authority is required to ensure not only that a private certifier is registered but that the work is within that certifier's authority. ${ }^{110}$ Where it is not within the inspector's authority, a territorial authority is not bound to accept the certificates and cannot rely on the good faith defence if they do. ${ }^{111}$

Even if wrong, Elias CJ noted that there are two potential options available and the uncertainty of facts required a full trial. ${ }^{112}$ The first is that when aggregating the negligence of multiple council employees there is an argument the good faith standard is breached by the conduct of the council as an entity. ${ }^{113}$ Secondly, because the procedures

\footnotetext{
${ }^{102}$ At [160]-[163] per William Young J.

103 At [151-152] per William Young J.

104 At [155]-[156] per William Young J.

105 At [32] per Elias CJ dissenting; [158]-[159] per William Young J; [173] per Tipping J.

106 At [32] per Elias CJ dissenting.

107 At [32] per Elias CJ dissenting.

108 At [30]-[32], [87]-[90] per Elias CJ dissenting.

109 At [30]-[32] per Elias CJ dissenting.

${ }^{110}$ At [30]-[32], [90] per Elias CJ dissenting.

111 At [89] per Elias CJ dissenting.

${ }^{112}$ At [32] per Elias CJ dissenting.

113 At [32] per Elias CJ dissenting.
} 
to verify certificates in place at the Auckland City Council were inadequate, council employees could not be said to be acting in good faith. ${ }^{114}$ On the facts of McNamara, as soon as a territorial authority accepted a private certifier-issued certificate, it was not acting with good faith as it did not perform adequate checks. ${ }^{115}$ As the Auckland City Council was not performing adequate checks it was failing in its responsibilities under the Act and all actions by employees were prima facie lacking good faith. ${ }^{116}$

\section{Outcome}

McNamara decided the Auckland City Council was not liable with Elias CJ dissenting and Tipping $\mathrm{J}$ agreeing in part. There is no duty of care owed when a private certifier has been engaged. ${ }^{117}$ This conclusion is based on the fact the Auckland City Council, before granting building consent, checked that $\mathrm{ABC}$ had the authority to certify for the project. $^{118}$ The purpose of the Act and the facts did not fulfil the modified Anns framework, failing both proximity and policy. ${ }^{119}$ A council is not required to investigate once the initial checks are completed. ${ }^{120}$ A duty under Spencer on Byron could only be 'enlivened' under s57, or if the council "well knew" that a certifier was acting outside their authority. ${ }^{121}$

For the reasons enunciated above, there was no proximity between the council and the McNamaras in relation to the Hedley Byrne claim. ${ }^{122}$ The council was bound to accept the certifier issued code compliance certificate and was not required to check the accuracy of the information contained within the certificate. ${ }^{123}$ The council presented factually accurate information in the LIM report, that a code compliance certificate had

\footnotetext{
${ }^{114}$ At [32] per Elias CJ dissenting.

115 At [90] per Elias CJ dissenting.

${ }^{116}$ At [90] per Elias CJ dissenting.

117 At [168] per William Young J.

${ }^{118}$ At [167] per William Young J.

119 At [164]-[168] per William Young J.

${ }^{120}$ See [164]-[168] per William Young J.

${ }^{121}$ At [168] assenting to NZCA discussions at [132] per William Young J.

122 See [146]-[163] per William Young J.

${ }^{123}$ At [170] per William Young J.
} 
been issued. ${ }^{124}$ A territorial authority is not liable for the substantive accuracy or the formal validity of a code compliance certificate when issuing a LIM report. ${ }^{125}$ Even if the majority had interpreted the facts incorrectly in light of the decision in Altimarloch, the s50(3) good faith defence would provide an alternative and prevent liability for the council. ${ }^{126}$

Tipping $\mathrm{J}$ agreed with the majority that the good faith defence under s50(3) applied to prima facie valid certificates. ${ }^{127}$ The references within s50(1) to s56 and s43 were meant generally and did not require the council to check the compliance of all certificates every time a new one is received. ${ }^{128}$ To require those checks would defeat the policy of the Act by placing unfair burdens on private certifiers that did not apply to council inspections. ${ }^{129}$ If s50 was read literally it would enable a negligence standard to defeat the good faith defence, stripping the defence of any meaningful effect. ${ }^{130}$

\section{$V$ Critical analysis}

\section{Issue One: Duty of Care to inspect}

For a duty to arise the two stage Anns test must be met and it must be "fair, just and reasonable" for that duty to exist. ${ }^{131}$ There must be proximity between the parties which can establish a duty of care and then policy reasons must be examined in order to determine if liability should exist as a matter of principle. ${ }^{132}$ Policy is often viewed as being detrimental to a duty but can enhance the proximity and solidify the claimed duty. A duty can also be established in a wide sense by proximity and narrowed by policy or vice versa. The scope of any duty given has a direct correlation to the actions required of

\footnotetext{
${ }^{124}$ See [169]-[170] per William Young J.

${ }^{125}$ See [169]-[170] per William Young J.

${ }^{126}$ At [170] per William Young J.

${ }^{127}$ At [178]-[179] per Tipping J.

${ }^{128}$ At [179] per Tipping J.

${ }^{129}$ At [160] per William Young J.

${ }^{130}$ At [160] per William Young J.

${ }^{131}$ Couch v Attorney General, above n26, at [52] per Elias CJ; [78] per Tipping J.

132 Todd The Law of Torts in New Zealand, above n12, at 151-156.
} 
a person. Without guidance a person cannot know whether their actions are reasonable, whether they have breached a duty or not. The issues of remoteness and causation are not generally relevant in relation to defective buildings ${ }^{133}$ but may be an issue when dealing with the facts of McNamara. Past cases such as Sunset Terraces have shown that the negligent inspections of houses have caused the damage, at least to an extent.

Defective buildings can be conceptualised in two ways. Either the inspection was negligent or the issuance of the compliance certificates was negligent. The damage is both in the value of the house and the safety and health of individuals who occupy or live within. The council is argued to have caused, at least to some degree, the damage to the house.

\section{Duty}

The duty argued by counsel for the McNamaras was a duty to check that the certificates provided by the building inspector were within the authority of that inspector. ${ }^{134} \mathrm{~A}$ corollary of this duty is that the territorial authority's responsibilities were 'enlivened' if the private certifier was acting outside their authority and the territorial authority were under a duty to inspect the building itself. ${ }^{135}$ This duty would cease to exist if the owner of the building engaged another private building certifier to inspect for those elements. In this respect the Majority are correct.

Territorial authorities are engaged in a role of ensuring that the building industry is adequately supervised. Their duty of care extends to the inspection, acceptance and issuance of certificates. This duty exists when either they themselves or a private inspector have completed the required inspections. These actions are the basis which Spencer on Byron extended the law to commercial buildings. ${ }^{136}$ There is no principled

\footnotetext{
133 See Sunset Terraces, above n19, per Tipping J.

${ }^{134}$ McNamara v Auckland City Council, above n3, at [126], [129] Per William Young J.

135 See McNamara v Auckland City Council, above n3, per Elias CJ.

136 Spencer and Byron, above n20, at [215]-[218] per McGrath and Chambers JJ.
} 
reason to exclude any part of the process based on any arbitrary distinction. ${ }^{137}$ There is a large general duty arising through reliance of the public on territorial authorities and the control territorial authorities have over the administration of the building process. These are the same elements, reliance and control, that have guided our understanding of this area of negligence through Hamlin and into the recent developments. ${ }^{138}$

This general duty provided the basis for a duty of care in defective buildings prior to the 1991 Building Act. It was not only the negligent inspections which caused a duty of care. The acceptance and cross-checking which should be present to prevent error or fraud are inherently required. A territorial authority can be negligent in both inspecting of and issuing code compliance certificates.

When the 1991 Act came into force this caused a shift in how liability would be accounted for. In some circumstances, when a private inspector was engaged, Parliament created a defence which prevented the council for being liable, the s50(3) good faith defence. Parliament did not negate the existing duty but placed a defence on top of that which prevented liability. The rationale behind this choice was to create competition in the building inspection industry by allowing private certifiers to be engaged and ensuring that territorial authorities did not effectively force them out of the market. The defence was a way of preventing territorial authorities requiring high fees for substantive analysis of the certificates submitted by private certifiers. This worked in conjunction with s50(1) which prevented the substantive checks by territorial authorities. It removed the potentially disastrous consequence of territorial authorities being liable for the substantive content of private certifier-issued certificates that they were prevented from inspecting. It is apparent that without s50(1) a territorial authority would be required to inspect the substantive content of certificates as well as the procedural validity. Where a private certifier has the authority and is registered, there is no liability for territorial authorities by virtue of the good faith defence. However, as this was a specific defence it

\footnotetext{
${ }^{137}$ See Spencer on Byron, above n20, [27]-[55] per Tipping J; See also McGrath and Chambers JJ.

138 Spencer and Byron, above n20, at [27]-[38] per Tipping J.
} 
does not destroy the relational proximity or negate the policy behind having protection through the tort of negligence.

Negligence for defective buildings can come from both the inspection and the acceptance of documents. Both are important to the public as a matter of faith and reliance on our building industry. Richardson $\mathrm{J}$ and Cooke $\mathrm{P}$ stressed the unique situation in New Zealand in Hamlin and those policy reasons flow through both jobs required of territorial authorities. $^{139}$

Both the inspection and the inherent approval of the inspection through acceptance of compliance certificates are distinct yet important roles, strengthened by the implementation of the 1991 Act. Before the 1991 Act it was clear when accepting a certificate that the person was authorised to issue it as they were an employee of the territorial authority. However, a check should have occurred to ensure that the inspection was completed with the proper formalities. After the 1991 Act the importance of this secondary checking role was enhanced with the registration and authority of private certifiers. A territorial authority owes a duty of care to owners and subsequent purchasers that the certificates they accepted for code compliance met all the procedural requirements. If they did not meet the procedural requirements then the council was not allowed or obliged to accept the certificate. ${ }^{140}$ Once this occurred it can be reasoned that the council owed a duty to properly inspect the building for the elements that the private certifier was not authorised for. Nearly all breaches of the duty to inspect the building will have a causal link to the damage. Many of the breaches of the second duty to inspect the validity of certificates will not have this link and causation will limit the liability. It is in the causation and breach elements where the case of McNamara was required to be decided, not duty.

\footnotetext{
${ }^{139}$ See Invercargill City Council v Hamlin, above n17 per Richardson, Cooke JJ.

${ }^{140}$ Building Act 1991, s50(1).
} 


\section{Breach}

Applying the facts of McNamara, the Auckland City Council ignored its duty to check the formalities required when $A B C$ submitted weather tightness certification. After $4^{\text {th }}$ December 2002 it can be said that this breach may have caused the damage. Through this negligence Auckland City Council failed in their duty to inspect for the weather tightness standards themselves. By having a framework that only checked at first instance the council was relying on actions such as those undertaken by the BIA and ABC to review ABC's open files. It appears that that review was negligent, at least in relation to the Arney Crescent property as it did not highlight the Arney Crescent property as requiring a territorial authority to commence inspections. ${ }^{141}$ As the review was a voluntary act by a third party it does not revoke the Auckland City Council's duty to check the formalities of building inspectors when they submit inspections, at least at regular intervals. A reasonable person, in the shoes of a council employee would be required to check the authority of a private certifier on a regular basis. The exact length of that 'regular basis' may not require a check each time a certificate is received as it may be too costly or time consuming. Checks would be required to be at least more regularly than in McNamara. The external factor of $\mathrm{ABC}$ requiring multiple territorial authorities to take over inspections and the leaky building reports would have put a council 'on alert'. ${ }^{142}$ This would require more inspections than at a time when there was no heightened risk.

This is not to say that a council will always be in breach. If a territorial authority inspects the authority regularly, or submits contested procedural checks to the BIA under s17, then it is likely we would not consider it breaching the duty owed. ${ }^{143}$ If, in a difficult situation a building appears to meet a certain standard and is accepted by the territorial authority and it was reasonable for them to do so, then they may not have breached this standard either.

\footnotetext{
${ }^{141}$ See McNamara v Auckland City Council, above n3, per Elias CJ on BIA review.

142 See McNamara v Auckland City Council, above n3, per Elias CJ.

143 Building Act 1991.
} 


\section{Causation}

In defective building cases causation is seldom raised, the prima facie 'but for' test generally answers the question affirmatively. There are generally no questions over the nature of the damage or whether it was actually caused by the inspections. What worried the majority in McNamara was that utilising the s50(3) good faith defence by requiring the strict s56 requirements to be met may open liability up in a number of areas. ${ }^{144}$ This may prove to be an unfounded fear. In a situation where the requirements of s56 are met, but because of the lack of checking of the certifier's competency the good faith defence does not apply, causation may intervene. A duty may be breached but it cannot be said that the breach has caused any of the harm that has occurred. If a territorial authority had checked then it would have been bound to accept the certificate. In this instance it can be said that the territorial authority were lucky, but that their negligent actions did not cause any damage. As the issue, in this hypothetical scenario, is with the substantive formulation of the certificate s50(1) is engaged and the s50(3) good faith defence is available.

\section{Remoteness}

Remoteness was not raised in McNamara and it is difficult for a situation to arise where it may be at issue. The damage is inextricably linked to the failure to inspect properly and acceptance of compliance documentation outside private certifiers' authority. Water damage is of the type of damage that would be expected from a failure of a weathertightness standard. This does not necessarily mean this will follow in all defective building cases, but will require a rare set of facts for this to be an issue.

\section{$9 \quad$ Liability in a wider setting}

Liability for negligence in defective buildings is an odd development when viewing negligence in a wider scope. The wrong complained of is not that an action has caused physical harm to a person, nor is it that physical harm has been caused to another

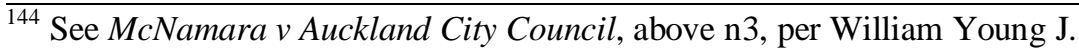


structure, such as a negligently constructed heater causing damage to a television. The damage in McNamara is an example of the loss type in Hedley Byrne and referred to as "pure economic loss”. ${ }^{145}$ The judges in cases for defective buildings have distanced themselves from calling the loss suffered by owners or subsequent purchasers as "pure economic loss”. ${ }^{146}$ This creates an anomaly in the law and although the explanations have been accepted, discomfort remains at a principled level.

The wrong complained of in McNamara is that the council negligently checked private certifier-issued certificates during the construction of a building and misstated, through acceptance of invalid certificates that the building conformed to the Building Code. It is very much akin to the acts alleged in negligent misstatement cases such as Scott Group $^{147}$, Boyd Knight ${ }^{148}$ or Caparo. ${ }^{149}$ Caparo is a leading case from the House of Lords about to whom an auditor owed a duty of care when their actions were negligent. ${ }^{150}$ Caparo decided that a duty of care could not extend to the general public based upon an auditor's report. ${ }^{151}$ The auditor, in conducting the audit report, was only liable to the company, through contract, and the owners of the company at the time of the audit report (the shareholders). ${ }^{152}$ Scott Group, a New Zealand authority decided that a duty of care did arise, at least when the kind of transaction was reasonably foreseeable. ${ }^{153}$ Boyd Knight tempered this by requiring high evidence of reliance. ${ }^{154}$ What is clear is that liability in New Zealand, has tended to support a wide interpretation of the principles of negligence. ${ }^{155}$ What is unclear from this analysis and glossed over in Sunset Terraces is

\footnotetext{
${ }^{145}$ Todd The Law of Torts in New Zealand, above n12, at 291.

${ }^{146}$ Sunset Terraces, above n19, at [29]-[30] per Tipping J; Spencer on Byron, above n20, at [41]-[45] per Tipping J; Spencer on Byron, above n20, at [241]-[244] per William Young J dissenting.

${ }^{147}$ Scott Group v McFarlane and Others [1978] 1 NZLR 553.

${ }^{148}$ Boyd Knight v Purdue [1999] 2 NZLR 278 (CA).

${ }^{149}$ Caparo Industries plc v Dickman [1990] 2 AC 605 (HL).

${ }^{150}$ Caparo Industries plc v Dickman [1990] 2 AC 605 (HL).

${ }^{151}$ Todd The Law of Torts in New Zealand, above n12, at 227-230.

152 Todd The Law of Torts in New Zealand, above n12, at 227-230.

${ }^{153}$ See Scott Group v McFarlane and Others, above n148 at 582 per Cooke J.

154 Todd The Law of Torts in New Zealand, above n12, at 229-230.

155 See Spencer on Byron, above n20; Scott Group v McFarlane, above n148; see also Caparo Industries plc v Dickman, above n149.
} 
why defective buildings, given the similarities of the facts have a relatively easier test to satisfy. ${ }^{156}$ It is extremely odd that this divergence has occurred especially in relation to the English position in Caparo. Whether the law develops in a manner which restricts liability in negligent misstatement claims in line with narrower test in Caparo or accepts that the formulation as in Spencer on Byron is beyond the scope of this paper. What is necessary is that the correct principles of the law must be enunciated so the negligent misstatement segments can be properly aligned.

\section{The 2004 Building Act}

The 2004 Building Act has been said to change very little in the area of negligence for defective buildings. ${ }^{157}$ The warranties inserted into the 2004 Act have limited value and many proceedings on which the courts have adjudicated would fall outside these limited categories. ${ }^{158}$ The 2004 Act, through provisions which include the continuance of negligence has, in effect, assented to the burden of the duty of care. ${ }^{159}$ What the 2004 Building Act may achieve, through a more prescriptive style of building standards is safer and less leaky houses in the future. A major part of the defective building tort compromises of claims for leaky buildings. The general population seems happy with the allocations of responsibility placed on stakeholders in the building process by the Courts. Parliament has not acted to mitigate those responsibilities but to fix the flawed Building Code which created those issues.

The duty of care for defective buildings and the standard for that duty of care does not appear to have been altered by the new legislation. However a case directly on this point is not before the Supreme Court and this question may not be answered in the immediate future.

\footnotetext{
${ }^{156}$ See Sunset Terraces, above n19.

157 Spencer on Byron, above n20, at [217] per McGrath and Chambers JJ; Sunset Terraces; above n19, at [1] per Elias CJ.

${ }^{158}$ Sharp “Spencer on Byron”, above n25, at 197; Building Act 2004, ss396-399.

${ }^{159}$ Building Act 2004, s391.
} 


\section{E Issue Two: Negligence for LIM reports}

The space restrictions of this paper do not allow this issue to be fully analysed. The argument on issue two was foreshadowed in the Court of Appeal and the conclusion of the majority appears contrary to the established authority of Altimarloch. It is difficult to reconcile the two developments of the law and requires further analysis as the situations appear to have similar facts in relation to a LIM request. Liability for the accuracy of LIM reports utilising Hedley Byrne theories may have wide-ranging implications on society and is best addressed by either Parliament or a case where the primary focus is Hedley Byrne liability.

In brief, there are two potential meanings that can be derived from these cases. The first is that a territorial authority is liable for the accuracy of information in LIM reports. The second is that a territorial authority is liable for the accuracy of information in LIM reports unless the substantive accuracy of that information is not within the councils knowledge. This is the meaning seemingly hinted at in McNamara.

Altimarloch featured water rights that a council officer knew (or ought to have known) had changed but were not altered on the LIM report. ${ }^{160}$ McNamara features a code compliance certificate which the council knew (or ought to have known) was not issued by a certifier who had the authority to issue it for weather tightness, yet was listed (or accepted as being listed) on the LIM report. ${ }^{161}$

As a council officer is not expected to check the substantive content of all the information in a LIM report before presenting a copy to the public, the situation appears to be the same in both situations. It is unlikely that the information contained in LIM reports is so different in style or form that it allows the judiciary to pick and choose where liability should fall.

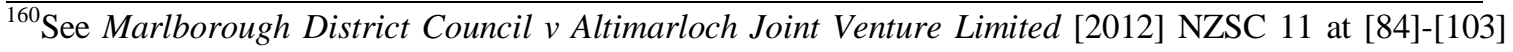
per Tipping J.

${ }^{161}$ McNamara v Auckland City Council, above n3,, at [169] per William Young J.
} 
McNamara creates an anomaly in the law of negligent misstatements and also inhibits territorial authorities from knowing the true position of their liability for the accuracy of information contained in LIM reports.

\section{F Issue Three: The s50(3) good faith defence}

The good faith defence has been accepted to be a lower standard in certain situations. ${ }^{162}$ McNamara is not a case where the exact standard of good faith is of central relevance to the decision. William Young J assumes this to mean an absence of bad faith. ${ }^{163}$ For the purposes of this paper the author is willing to accept that conclusion although the formulations of Elias CJ may require analysis if good faith itself is questioned, rather than technical requirements before the good faith defence can arise.

It is difficult to reconcile the established duty of care in defective buildings with the analysis of the majority and Tipping $\mathrm{J}$ in respect of their reading of s50(1). ${ }^{164}$ Defective building liability is built on the reliance of the public in respect of the inspection process carried out by territorial authorities. With the introduction of private inspectors, this reliance has continued although home owners may now choose to engage territorial authorities or not. The deemed reliance placed on territorial authorities includes a reliance that they will check that a private certifier-issued certificate is within that certifier's authority.

This reliance is a key to understanding the section. Liability continues as long as a territorial authority conducts certain procedural checks before accepting certificates. In order to provide clarity in this area, Parliament made specific reference within s50(1) to what was required before the s50(3) defence could be utilised. Referring to s56 and s43 provided a framework that territorial authorities had to operate within in order for the substantive protection to arise. The substantive protection prevented liability for territorial authorities in situations where the contents of the certificate were erroneous. As

\footnotetext{
${ }^{162}$ At [173] per Tipping J.

${ }^{163}$ At [149],[160]-[163] per William Young J.

${ }^{164}$ See Page 14-15.
} 
s43 refers to s56 in the acceptance of certificates, s56 must be followed closely requiring a number of procedural checks. Like any defence, the specific elements must all be met before the defence can be engaged, even if this may cause some odd situations. One of those requirements is to check that the private certifier has the authority to issue that certificate.

On the facts of McNamara after $4^{\text {th }}$ December 2002, ABC Ltd did not have the authority to issue certificates for the weather-tightness standard E2. As the certificates issued were not within ABC's limited authority under E2/AS1 to a reasonably informed person s50(3) cannot be engaged. ${ }^{165}$

If the view of the majority and Tipping $\mathrm{J}$ on the interactions of the sections were to be approved it would be encouraging negligence by council workers when accepting privatecertifier issued certificates rather than requiring strong safety checks. Whilst the author accepts that a compromise between the strength of those safety checks and the costs associated may create some ambiguity as to how often these checks are required, the factual situation and circumstances of the time will point towards what is required before a breach occurs.

Auckland City Council did not check the authority of $A B C$ limited in issuing the code compliance certificate or any weather-tightness standards under E2 after $4^{\text {th }}$ December 2002. As such these certificates do not fulfil the s56 requirements and cannot be relied upon for the purposes of s50. This means that the good faith defence is not available to the Auckland City Council for issue one and does not stretch to prima facie valid certificates.

The good faith defence applies broadly to any good faith reliance on documents that are included, even in other functions. In relation to LIM reports the question is whether the employee, upon issuance of the LIM report, is acting in good faith. It is impractical to require council employees to check the validity of all information contained in the LIM

$\overline{165}$ McNamara v Auckland City Council, above n3, At [69] per Elias CJ dissenting. 
report before issuing it to the public. The majority interpretation of good faith requiring actual knowledge may present fewer complexities when applied broadly than the ideas of Elias CJ. As such, in the Hedley Byrne scenario for the information contained in the LIM report the McNamara family, or anyone in a similar position, are unlikely to succeed when claiming.

\section{Conclusion}

By utilising the negligence framework many of the issues raised by the majority and Tipping $\mathrm{J}$ in McNamara can be alleviated. The Breach requirement may protect territorial authorities when it was not reasonable for them to have either concluded without special advice or checked every time a certificate is issued. Breach is a powerful requirement when dealing with difficult duty of care questions. It helps underline the misinterpretation of the majority as a lot of their analysis is phrased in duty terminology but is best placed under breach. Their conclusions do raise a number of pertinent points that can help guide our understanding. ${ }^{166}$ The discussion of backstop liability helps us frame the concern that to extend liability too far can be counter-productive to society. To hold a territorial authority liable for the building process when they did not undertake inspections but contracted them out is also counter-intuitive unless the facts dictate that a situation warrants an exception on a principled basis.

Coupled with the limitations the breach element can place on the proposed extension of liability for territorial authorities, causation can temper the narrower formulation of the good faith defence postulated in this paper. That before s50(3) could be relied on the s56 criteria must be met. The good faith defence is intended to protect territorial authorities who meet certain standards from being liable for the substantive contents of privatecertifier issued certificates. If a territorial authority conducts adequate checks to ensure that the private certifier acted within their authority any reliance on those certificates is protected by virtue of the statutory good faith defence in s50(3). When inadequate checks have taken place, the protection of s50(3) is not available and the territorial authorities are prima facie liable under a Spencer on Byron analysis. Causation can reduce the potential

${ }^{166}$ See McNamara v Auckland City Council, above n3 per William Young J. 
impacts of this by requiring a causal link between the failure to check for compliance and the damage caused. In most situations if the certifier did meet all the s56 standards then that link will not be proven and territorial authorities will not be liable.

The Supreme Court in McNamara altered the existing doctrines of New Zealand law and limited liability in a novel situation. In her dissent the Chief Justice questioned many aspects of the decision, in particular the effectiveness of that decision in upholding the underlying policy behind the tort of negligence. This author agrees with many of her conclusions, with particular emphasis on not allowing "an unaccountable gap in the regulatory system" ${ }^{167}$. The importance of home ownership has been fundamental to the development of this special duty of care and the reasoning of Cooke P and Richardson $\mathrm{J}$ in Hamlin are said to still be pertinent to this day, although this is arguable in light of Spencer on Byron. A council should be acting to the highest level it can when involved in the building consent process, and any actions with the potential for fraud or misappropriation require checks that prevent these actions. Requiring the procedural checks on a regular basis for the requirements of s56, including that a certificate is within the private certifier's authority helps achieve public confidence in the building system.

The decision in McNamara is incorrect when analysed within the accepted negligence framework and the factual scenario works without opening the 'floodgates of litigation'. Negligence may not always lead to the result a party wishes and as explained by this paper, sometimes the elements of breach and causation may exempt a party from liability. The McNamara family deserved an opportunity for full evidence to be placed in Court so that the correct decision with regard to all the facts could be reached. This opportunity was not afforded to them or the potential class of litigants who fall within this category.

${ }^{167}$ McNamara v Auckland City Council, above n3, at [13] per Elias CJ dissenting. 


\section{VIIAppendix A}

11 Building Act 1991 ss50,43, 56 168

50 Establishing compliance with building code

(1) A territorial authority shall accept the following documents as establishing compliance with the provisions of the building code:

(a) A building certificate or code compliance certificate to that effect issued by a building certifier under section 43 or section 56 of this Act:

(3) For the avoidance of doubt, no civil proceedings may be brought against a territorial authority or a building certifier for anything done in good faith in reliance on a document set out in subsection (1) or subsection (2) of this section.

43 Code compliance certificate

(1) An owner shall as soon as practicable advise the territorial authority, in the prescribed form, that the building work has been completed to the extent required by the building consent issued in respect of that building work.

(2) Where applicable, the owner shall include with that advice either-

(a) Any building certificates issued by building certifiers under section 56 of this Act to the effect that any items of the building work comply with specified provisions of the building code; or

(b) A code compliance certificate issued by a building certifier under this section and section 56(3) of this Act to the effect that all of the building work complies with each of the relevant provisions of the building code.

56 Issue of building certificates

(1) A building certificate issued by a building certifier under this section shall-

(a) Be in writing; and

(b) Identify the specific item or items that are the subject of the certificate, being items not excluded by any limitation on the building certifier's approval; and

${ }^{168}$ Building Act 1991, ss 43, 50, 56. 
(c) Identify the specific provisions of the building code with respect to which those items are certified, being specific provisions in respect of which the building certifier is approved; and

(d) Be signed by the building certifier; and

(e) Be accompanied by any relevant project information memorandum.

(3) A building certifier may issue a code compliance certificate, in the prescribed form, pursuant to section 43 of this Act if the building certifier is satisfied on reasonable grounds that the building work complied with the provisions of the building code on the date of certification.

(Emphasis added)

\section{Appendix B}

\section{Acceptable Solution ${ }^{169}$}

A prescriptive design solution comprising step-by-step instructions which, if followed, is deemed to comply with the Building Code. Acceptable Solutions and Verification Methods are contained in the Ministry's Compliance Documents, and often quote other documents such as New Zealand Standards. Designers and builders are not obliged to use Acceptable Solutions, and may put forward their own alternative solution proposal. Find out more.

13 Clause E2-EXTERNAL MOISTURE ${ }^{170}$

Provisions

Limits on application

OBJECTIVE

E2.1 The objective of this provision is to safeguard people from illness or injury which could result from external moisture entering the building.

169 Department of Building and Housing "Building A-Z” < www.dbh.govt.nz>.

${ }^{170}$ Building Regulations 1992, Schedule 1, clause E2. 
Provisions

FUNCTIONAL REQUIREMENT

E2.2 Buildings shall be

provide adequate resistance to penetration by, an accumulation of, moisture from the outside.

\section{PERFORMANCE}

E2.3.1 Roofs shall shed precipitated moisture. In locations subject to snowfalls, roofs shall also shed melted snow.

E2.3.2 Roofs and exterior walls shall prevent the penetration of water that could cause undue dampness, or damage to building elements.

E2.3.3 Walls, floors and structural elements in contact with the ground shall not absorb or transmit moisture in quantities that could cause undue dampness, or damage to building elements.

E2.3.4 Building elements susceptible to damage shall be protected from the adverse effects of moisture entering the space below suspended floors.

E2.3.5 Concealed spaces and cavities in buildings shall be constructed in a way which prevents external moisture being transferred and causing condensation and the degradation of building elements.

E2.3.6 Excess moisture present at the completion of construction, shall be capable of being dissipated without permanent damage to building elements.
Limits on application

to Requirement E2.2 shall not apply to more harmful than those likely to arise ind use. 


\section{Bibliography \\ G Cases;}

14 New Zealand

Boyd Knight v Purdue [1999] 2 NZLR 278 (CA).

Body Corporate No. 207624 v North Shore City Council [2012] NZSC 83 [Spencer on Byron].

Bowen v Paramount Builders (Hamilton) Ltd [1977] 1 NZLR 394 (CA).

Couch v Attorney General [2008] NZSC 45.

Invercargill City Council v Hamlin [1996] 1 NZLR 513 (PC).

Invercargill City Council v Hamlin [1994] 3 NZLR 513 (CA).

Marlborough District Council v Altimarloch Joint Venture Limited [2012] NZSC 11

McNamara v Auckland City Council [2012] NZSC 34.

McNamara \& Anor as trustees of the PH McNamara Family Trust v Malcolm J Lusby

Ltd \& Ors HC Auckland CIV 2006-404-002967, 10 September 2009 at [2].

Murphy v Brentwood District Council [1990] 2 All ER.

North Shore City Council v Body Corporate 188529 [2010] NZSC 158 [Sunset Terraces].

North Shore City Council v Attorney-General as Successor to the Assets and Liabilities of the Building Industry Authority [2012] NZSC 49 [The Grange].

North Shore City Council v Attorney General as Successor to the Assets and Liabilities of the Building Industry Authority [2010] NZCA 324.

Scott Group v McFarlane and Others [1978] 1 NZLR 553.

Queenstown Lakes District Council v Charterhall Trustees Ltd [2009] NZCA 374

15 Australia

Mid Density Developments PTY LTD v Rockdale Municipal Council (1993) 44 FCR 290.

16 United Kingdom

Caparo Industries plc v Dickman [1990] 2 AC 605 (HL). 


\section{H Legislation;}

17 New Zealand

Building Act 1991.

Building Act 2004.

18 Subordinate legislation

Building Regulations 1992, reg 150.

\section{Australian}

Environmental Planning and Assessment Act 1979 (NSW).

\section{Books and chapters in books;}

B Atkin and G McLay Torts in New Zealand Cases and Materials $95^{\text {th }}$ ed, Oxford University Press, Melbourne, 2012).

Stephen Todd (ed) The Law of Torts in New Zealand $\left(6^{\text {th }}\right.$ ed, Brookers, Wellington, 2013).

\section{J Journal articles;}

Russell Brown “Assumption of Responsibility and Loss of Bargain in Tort Law” (2006) 29.2 Dalhousie Law Journal 345.

Michael Sharp “Spencer on Byron” (2013) 5 NZLJ 195.

Rosemary Tobin “Queenstown Lakes District Council v Charterhall Trustees Ltd” (2009) 13 BCB 213.

Rosemary Tobin “North Shore City Council v Body Corporate 188529 (Sunset Terraces); North Shore City Council v Body Corporate 189855 (Byron Avenue)” (2011) 14 BCB 104.

Rosemary Tobin "Leaky commercial buildings and council liability” [2012] NZLJ 333.

Rosemary Tobin “Tortious liability for defective building revisited” (2008) 13 BCB 49. 


\section{K Reports;}

Bannister and von Dadelszon LIM (Land Information Memorandum) Reports (Bannister and von Dadelszon, 2013).

Building Industry Commission Reform of Building Controls Volume I (January 1990).

Sophie East A New Class of Leaky Building Litigants? (Bell Gully, November 2012).

Pricewaterhouse Coopers Weathertightness: Estimating the Cost (Department of Building and Housing, July 2009).

Report of the Overview Group on the Weathertightness of Buildings to The Building Industry Authority (Department of Building and Housing, August 2002)

\section{Internet Resources}

Department of Building and Housing "Building A-Z” <www.dbh.govt.nz>.

\section{Word count}

The text of this paper (excluding table of contents, abstract, key words, footnotes, appendices and bibliography) comprises approximately 7,995 words. 